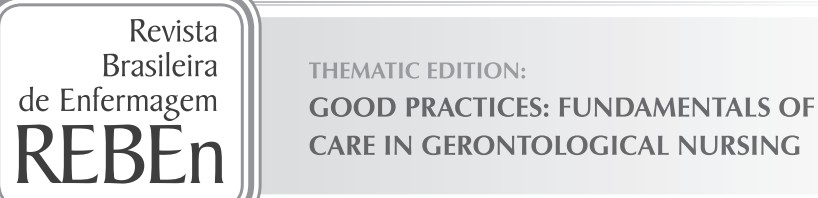

\title{
Frailty in the elderly: prevalence and associated factors
}

\author{
Fragilidade em idosos: prevalência e fatores associados \\ La fragilidad en ancianos: la prevalencia y los factores asociados
}

\section{Jair Almeida Carneiro ${ }^{1, I, I I I}$, Rafael Rodrigues Cardoso ${ }^{1, I V}$, Meiriellen Silva Durães', Maria Clara Araújo Guedes', Frederico Leão Santos", Fernanda Marques da Costa ${ }^{1, \text { II }}$, Antônio Prates Caldeirall,III}

' Universidade Estadual de Montes Claros, Department of Mental Health and Public Health. Montes Claros, Minas Gerais, Brazil.

"Faculdades Integradas Pitágoras de Montes Claros. Montes Claros, Minas Gerais, Brazil.

III Universidade Estadual de Montes Claros, Postgraduate Program in Health Sciences. Montes Claros, Minas Gerais, Brazil.

IV Universidade Estadual de Montes Claros, Foundation for Research Support of the State of Minas Gerais, Undergraduate Research Mentorship. Montes Claros, Minas Gerais, Brazil.

\begin{abstract}
Carneiro JA, Cardoso RR, Durães MS, Guedes MCA, Santos FL, Costa FM, et al. Frailty in the elderly: prevalence and associated factors. Rev Bras Enferm [Internet]. 2017;70(4):747-52. [Thematic Edition "Good Practices: Fundamentals of care in Gerontological Nursing"] DOI: http://dx.doi.org/10.1590/0034-7167-2016-0633
\end{abstract}

How to cite this article:

Submission: 12-12-2016

Approval: 04-02-2017

\section{ABSTRACT}

Objective: to know the prevalence and factors associated with frailty in elderly assisted by the Centro Mais Vida de Referência em Assistência à Saúde do Idoso (Mais Vida Health Reference Center for the Elderly) in the North of Minas Gerais, Brazil. Method: cross-sectional study, with sampling by convenience. Data collection occurred in 2015. Demographic and socioeconomic variables, morbidities, use of health services and the score of the Edmonton Frail Scale were analyzed. The adjusted prevalence ratios were obtained by multiple analysis of Poisson regression with robust variance. Results: 360 elderly aged 65 or older were evaluated. Frailty prevalence was $47.2 \%$. The variables associated with frailty were the following: advanced age elderly, who live without a partner, have a caregiver, present depressive symptoms, osteoarticular disease, as well as history of hospitalization and falls in the last twelve months. Conclusion: knowledge of factors associated with frailty allows development of health actions aimed at the elderly.

Descriptors: Elderly; Frail elderly; Health Vulnerability; Health of the Elderly; Public Health.

\section{RESUMO}

Objetivo: conhecer a prevalência e fatores associados à fragilidade em idosos assistidos pelo Centro Mais Vida de Referência em Assistência à Saúde do Idoso ao norte de Minas Gerais, Brasil. Método: estudo transversal, com amostragem por conveniência. A coleta de dados ocorreu em 2015. Analisaram-se variáveis demográficas e socioeconômicas, morbidades, utilização de serviços de saúde e o escore da Escala de Fragilidade de Edmonton. As razões de prevalências ajustadas foram obtidas por análise múltipla de regressão de Poisson com variância robusta. Resultados: foram avaliados 360 idosos com idade igual ou superior a 65 anos. A prevalência de fragilidade foi $47,2 \%$. As variáveis associadas à fragilidade foram: idosos longevos, que vivem sem companheiro(a), possuem cuidador, apresentam sintomas depressivos, doença osteoarticular, bem como história de internação e de quedas nos últimos 12 meses. Conclusão: o conhecimento dos fatores associados à fragilidade permite que ações de saúde destinadas a idosos possam ser desenvolvidas.

Descritores: Idoso; Idoso Fragilizado; Vulnerabilidade em Saúde; Saúde do Idoso; Saúde Coletiva.

\section{RESUMEN}

Objetivo: identificar la prevalencia y los factores asociados a la fragilidad en ancianos asistidos por el Centro Mais Vida, programa de Asistencia a la Salud del Anciano en el norte de Minas Gerais, Brasil. Método: estudio transversal, con muestreo por conveniencia. Se recolectaron los datos en el 2015. Se evaluaron las variables demográficas y socioeconómicas, comorbilidades, utilización de servicios de salud y el puntaje de la Escala de fragilidad de Edmonton. Se empleó el análisis múltiple de regresión de Poisson con varianza robusta para obtener las tasas de prevalencias ajustadas. Resultados: se evaluaron a 360 ancianos de más de 65 años de edad. Un 47,2\% fue la tasa de prevalencia de fragilidad. Las variables asociadas a la fragilidad fueron: 
ancianos longevos, que viven sin compañero(a), tienen cuidador, presentan síntomas depresivos, enfermedad osteoarticular e historial de hospitalización y de caídas durante los últimos 12 meses. Conclusión: conocer los factores asociados a la fragilidad en ancianos permite desarrollar acciones de salud dirigidas a ellos.

Descriptors: Anciano; Anciano Frágil; Vulnerabilidad en Salud; Salud del Anciano; Salud Colectiva.

CORRESPONDING AUTHOR Jair Almeida Carneiro Email: jairjota@yahoo.com.br

\section{INTRODUCTION}

Particularities related to the aging process have become more evident considering the increase in the proportion of older people observed in the general population. Such phenomenon has been happening in all countries, especially in developing countries, such as Brazil ${ }^{(1-2)}$.

Progressive and fast increase of elderly Brazilian population points out new challenges to the health sector, due to change in the epidemiological profile of the country caused by the increasing prevalence of chronic non-communicable diseases (NCD). Such clinical conditions can expose the elderly to a state of vulnerability due to poor resolution of homeostasis after a stress event, a result of the cumulative decline in various physiological systems over life, which is an essential frailty characteristic in the elderly ${ }^{(1,3-7)}$.

Frailty in the elderly is a multi-dimensional syndrome that involves interaction of biological, psychological and social factors. It is associated with a higher risk of adverse outcomes, such as decline in functional ability, falls, delirium, institutionalization, hospitalization and death ${ }^{(6-7)}$

Regarding the need to implement a health care network for the elderly population, the Department of Health of the State of Minas Gerais established the Mais Vida Program and the Rede de Atenção à Saúde do Idoso do Estado de Minas Gerais (Health Care Network for the Elderly in the State of Minas Gerais) ${ }^{(8)}$. This program is based on the constitution of an integrated network of health care for the elderly, with emphasis on Centros de Referência para Assistência à Saúde do Idoso (CRASI - Health Reference Centers for the Elderly), in which assistance is offered by a multidisciplinary team and there are counter-reference activities for basic health units.

One of the centers of the Mais Vida Program is located in the North of Minas Gerais and is a reference for 96 municipalities in the region. The profile of the population assisted is still little known and so far there are no studies that assess the level of frailty of the elderly directed to it. Knowledge of health conditions of the elderly is essential in such a way that strategies aimed at a healthy aging with a lower level of frailty can be developed and applied to this population. This study aims to verify prevalence and factors associated with frailty in elderly assisted by a CRASI in the North of Minas Gerais.

\section{METHOD}

\section{Ethical aspects}

All participants were provided with information on the research and agreed to participate by signing an Informed Consent Form. The research project was approved by the Research Ethics Committee of the Unimontes through the consolidated opinion.

\section{Study design, location and period}

This is a cross-sectional and analytical research. The host city of the study, Montes Claros, MG, has approximately 400.000 inhabitants and represents the main regional urban pole. Data collection was conducted in the first semester of 2015.

\section{Population or sample; inclusion and exclusion criteria}

The group evaluated was selected from convenience sampling, not intentional, according to the demand met, between May and July 2015, considering random selection difficulty. Data were primarily collected through direct contact and interviews with the target population. The interviewers were previously trained and calibrated. The elderly whose caregiverss or family members refused to participate in the study were excluded. Elderly aged 60 to 64 were also excluded, since the instrument used to evaluate frailty was validated only for people aged 65 or older.

\section{Study protocol}

The data-gathering instrument used was based on population-based similar studies, and was previously tested in a pilot study. The dependent variable was the record of frailty in the elderly, measured by the Edmonton Frail Scale (EFS), culturally adapted and validated for the Portuguese language ${ }^{(9)}$.

This is an instrument that assesses nine domains: cognition, state of health, functional independence, social support, medication, nutrition, humor, urinary continence and functional performance, distributed in 11 items with scores from 0 to 17. EFS score can vary between $0-4$, indicating that there is no presence of frailty; 5-6, apparently vulnerable to frailty; 7-8, mild frailty; 9-10, moderate frailty; and 11 or more severe frailty ${ }^{(10)}$.

In this study, for data analysis, the dependent variable results were dichotomized at two levels: without frailty (final score $\leq 6$ ) and with frailty (final score $>6$ ). Independent variables studied were: sex, age (65-79 years old and $\geq 80$ years old), self-reported skin color (white and non-white), marital status (with a mate, including married and consensual marriage; and without a mate, including single, widowed and divorced), condition of living alone or with others, education (up to four years of education and more than four years of education), knows how to read (yes and no), personal income (yes and no), monthly household income (up to a minimum wage and higher than a minimum wage),presence of self-reported NCD (hypertension, diabetes mellitus, heart disease, osteoarticular diseases, osteoporosis, cerebrovascular accident), depressive symptoms, according to the Geriatric Depression Scale score ( $\geq 6$ points and $<6$ points), presence of a caregiver, as well as record of fall and hospitalization in the past year.

\section{Analysis of results and statistics}

Prevalence ratios were calculated (PR) to investigate the existence of associations between the independent variables and 
frailty. Adjusted prevalence ratios were obtained through multiple analysis of Poisson regression with robust variance, considering independent variables that were more strongly associated with frailty in bivariate analysis (up to the level of significance $<0.20)$. For the final analysis, a $0.05(p<0.05)$ final significance level was considered.

Information collected was analyzed through the program Statistical Package for the Social Sciences (SPSS) version 17.0 (SPSS for Windows, Chicago, USA).

\section{RESULTS}

Participants of the study were 360 elderly aged 65 or older. The predominant age group was aged between 65 and 79, representing $75.3 \%$ of the population under study. The mean age of the group was $75(\mathrm{SD} \pm 7.6)$. Most of the elderly were female $(78 \%)$, lived without a mate $(83 \%)$, referred skin color as non-white $(62.5 \%)$, reported having their own income $(97.5 \%)$ and had up to four years of education $(85.8 \%)$.

Frailty prevalence was $47.2 \%$, being higher for females (48.8\%) compared with males (41.8\%). A prevalence of frailty even higher was noticed on older age groups $(41.3 \%$ between 65 and 79 years old and $65.2 \%$ aged 80 or older). Other features of the group demonstrated that $67.8 \%$ did not have a caregiver. Hospitalization register in the past year (with a permanence time higher than 24 hours) was mentioned by $21 \%$. Self-reported morbidity aspects investigated showed that $76.9 \%$ were hypertensive, $54.4 \%$ of the elderly suffered fall in the past year, $43.9 \%$ reported osteoarticular diseases, $37.2 \%$ showed symptoms of depression, $34.2 \%$ had osteoporosis, $21.9 \%$ had heart disease, $20.3 \%$ had diabetes and $10.6 \%$ had history of cerebrovascular accident. The bivariate analysis between frailty and other variables are presented in Tables 1 and 2.

After multiple analysis, the variables that remained statistically associated with frailty were: age 80 or older, marital status being without a mate, presence of depressive symptoms, presence of a caregiver, osteoarticular disease as well as history of hospitalization and falls in the past twelve months (Table 3).
Table 1 - Result of bivariate analysis between frailty and demographic, social and economic variables in the elderly assisted in the Mais Vida Health Reference Center for the Elderly, Montes Claros, Minas Gerais, Brazil, $2015(\mathrm{~N}=360)$

\begin{tabular}{|c|c|c|c|c|c|c|c|}
\hline \multirow[t]{3}{*}{ Independent variables } & \multicolumn{4}{|c|}{ Frailty } & \multirow{3}{*}{ PR } & \multirow{3}{*}{$95 \% \mathrm{Cl}$} & \multirow{3}{*}{$\underset{\text { value }}{p}$} \\
\hline & \multicolumn{2}{|c|}{ No } & \multicolumn{2}{|c|}{ Yes } & & & \\
\hline & $\mathbf{n}$ & $\%$ & $\mathbf{n}$ & $\%$ & & & \\
\hline \multicolumn{8}{|l|}{ Sex } \\
\hline Female & 144 & 51.2 & 137 & 48.8 & 1 & & \\
\hline Male & 46 & 58.2 & 33 & 41.8 & 1.16 & $0.87-1.55$ & 0.27 \\
\hline \multicolumn{8}{|l|}{ Age group } \\
\hline $65-79$ & 159 & 58.7 & 112 & 41.3 & 1 & & \\
\hline$\geq 80$ & 31 & 34.8 & 58 & 65.2 & 1.57 & $1.28-1.94$ & 0.00 \\
\hline \multicolumn{8}{|l|}{ Self-reported skin color } \\
\hline White & 67 & 49.6 & 68 & 50.4 & 1 & & \\
\hline Others & 123 & 54.7 & 102 & 45.3 & 0.90 & $0.72-1.12$ & 0.35 \\
\hline \multicolumn{8}{|l|}{ Marital status } \\
\hline With a mate & 89 & 61.0 & 57 & 39.0 & 1 & & \\
\hline No mate & 101 & 47.2 & 113 & 52.8 & 1.35 & $1.06-1.71$ & 0.01 \\
\hline \multicolumn{8}{|l|}{ Family arrangement } \\
\hline Does not live alone & 151 & 50.5 & 148 & 49.5 & 1 & & \\
\hline Does not live alone & 39 & 63.9 & 22 & 36.1 & 0.72 & $0.51-1.03$ & 0.05 \\
\hline \multicolumn{8}{|l|}{ Educational level } \\
\hline$>4$ years & 33 & 64.7 & 18 & 35.3 & 1 & & \\
\hline $0-4$ years & 157 & 50.8 & 152 & 49.2 & 1.39 & $0.94-2.05$ & 0.06 \\
\hline \multicolumn{8}{|l|}{ Knows how to read } \\
\hline No & 120 & 56.9 & 91 & 43.1 & 1 & & \\
\hline Yes & 70 & 47.0 & 79 & 53.0 & 1.22 & $0.99-2.26$ & 0.06 \\
\hline \multicolumn{8}{|l|}{ Own income } \\
\hline Yes & 184 & 52.4 & 167 & 47.6 & 1 & & \\
\hline No & 6 & 66.7 & 3 & 33.3 & 0.70 & $0.27-1.77$ & 0.39 \\
\hline \multicolumn{8}{|l|}{ Household income } \\
\hline Higher than $\mathrm{R} \$ 880.00$ & 126 & 51.4 & 119 & 48.6 & 1 & & \\
\hline Up to $R \$ 880.00$ & 64 & 55.7 & 51 & 44.3 & 0.91 & $0.71-1.16$ & 0.45 \\
\hline
\end{tabular}

Note: PR - Prevalence Ratio; Cl - Confidence Interval.

Table 2 - Result of bivariate analysis between frailty and variables related to morbidities in the elderly assisted in the Mais Vida Health Reference Center for the Elderly, Montes Claros, Minas Gerais, Brazil, $2015(\mathrm{~N}=360)$

\begin{tabular}{|c|c|c|c|c|c|c|c|}
\hline \multirow[t]{3}{*}{ Independent variables } & \multicolumn{4}{|c|}{ Frailty } & \multirow{3}{*}{ PR } & \multirow{3}{*}{$95 \% \mathrm{Cl}$} & \multirow{3}{*}{$\underset{\text { value }}{p}$} \\
\hline & \multicolumn{2}{|c|}{ No } & \multicolumn{2}{|c|}{ Yes } & & & \\
\hline & $\mathbf{n}$ & $\%$ & $\mathbf{n}$ & $\%$ & & & \\
\hline \multicolumn{8}{|l|}{ Depression } \\
\hline No & 150 & 66.4 & 75 & 33.6 & 1 & & \\
\hline Yes & 40 & 29.9 & 94 & 70.1 & 2.08 & $1.68-2.58$ & 0.00 \\
\hline \multicolumn{8}{|l|}{ Arterial hypertension } \\
\hline No & 45 & 54.2 & 38 & 45.8 & 1 & & \\
\hline Yes & 145 & 52.3 & 132 & 47.7 & 1.06 & $0.82-1.37$ & 0.63 \\
\hline \multicolumn{8}{|l|}{ Diabetes mellitus } \\
\hline No & 153 & 53.5 & 133 & 46.5 & 1 & & \\
\hline Yes & 37 & 50.0 & 37 & 50.0 & 1.13 & $0.87-1.45$ & 0.35 \\
\hline
\end{tabular}

To be continued 
Table 2 (concluded)

\begin{tabular}{|c|c|c|c|c|c|c|c|}
\hline \multirow[t]{3}{*}{ Independent variables } & \multicolumn{4}{|c|}{ Frailty } & \multirow{3}{*}{ PR } & \multirow{3}{*}{$95 \% \mathrm{Cl}$} & \multirow{3}{*}{$\begin{array}{c}p \\
\text { value }\end{array}$} \\
\hline & \multicolumn{2}{|c|}{ No } & \multicolumn{2}{|c|}{ Yes } & & & \\
\hline & $\mathbf{n}$ & $\%$ & $\mathbf{n}$ & $\%$ & & & \\
\hline \multicolumn{8}{|l|}{ Heart disease } \\
\hline No & 154 & 54.8 & 127 & 45.2 & 1 & & \\
\hline Yes & 36 & 45.6 & 43 & 54.4 & 1.20 & $0.94-1.53$ & 0.14 \\
\hline \multicolumn{8}{|l|}{ Osteoarticular disease } \\
\hline No & 112 & 55.4 & 90 & 44.6 & 1 & & \\
\hline Yes & 78 & 49.4 & 80 & 50.6 & 1.13 & $0.91-1.41$ & 0.20 \\
\hline \multicolumn{8}{|l|}{ Osteoporosis } \\
\hline No & 64 & 52.0 & 59 & 48.0 & 1 & & \\
\hline Yes & 126 & 53.2 & 111 & 46.9 & 1.02 & $0.81-1.28$ & 0.83 \\
\hline \multicolumn{8}{|c|}{ Cerebrovascular accident } \\
\hline No & 179 & 55.6 & 143 & 44.4 & 1 & & \\
\hline Yes & 11 & 28.9 & 27 & 71.1 & 1.60 & $1.26-2.02$ & 0.00 \\
\hline \multicolumn{8}{|l|}{ Has a caregiver } \\
\hline No & 156 & 63.9 & 88 & 36.1 & 1 & & \\
\hline Yes & 34 & 29.3 & 82 & 70.7 & 1.96 & $1.59-2.40$ & 0.00 \\
\hline \multicolumn{8}{|c|}{ Fall in the past twelve months } \\
\hline Não & 99 & 60.4 & 65 & 39.6 & 1 & & \\
\hline Sim & 91 & 46.4 & 105 & 53.6 & 1.35 & $1.07-1.70$ & 0.00 \\
\hline \multicolumn{8}{|c|}{$\begin{array}{l}\text { Medical appointment in the } \\
\text { past twelve months }\end{array}$} \\
\hline No & 13 & 6.2 & 40 & 13.3 & 1 & & \\
\hline Yes & 198 & 93.8 & 260 & 86.7 & 1.38 & $0.27-6.86$ & 0.66 \\
\hline \multicolumn{8}{|l|}{$\begin{array}{l}\text { Hospitalization in the } \\
\text { past year }\end{array}$} \\
\hline No & 164 & 57.7 & 120 & 42.3 & 1 & & \\
\hline Yes & 26 & 34.2 & 50 & 65.8 & 1.55 & $1.26-1.92$ & 0.00 \\
\hline
\end{tabular}

Note: PR - Prevalence Ratio; CI - Confidence Interval.

Table 3 - Factors associated with frailty in the elderly assisted by the Mais Vida Health Care Center for the Elderly in the North of Minas Gerais, Brazil

\begin{tabular}{lccc}
\hline Independent variables & PR & $\mathbf{9 5 \%} \mathbf{C l}$ & $\boldsymbol{p}$ value \\
\hline Age & & & \\
$\quad 65-79$ & 1 & & \\
$\quad$ 80 years old or older & 1.24 & $1.02-1.51$ & 0.02 \\
Marital status & & & \\
$\quad$ With a mate (married/consensual marriage) & 1 & & 0.02 \\
$\quad$ No mate & 1.27 & $1.02-1.58$ & \\
Has a caregiver & & & \\
$\quad$ No & 1 & & \\
$\quad$ Yes & 1.58 & $1.30-1.92$ & 0.00 \\
Depressive symptoms & & & \\
$\quad$ No & 1 & & \\
$\quad$ Yes & 2.02 & $1.65-2.47$ & 0.00 \\
Osteoarticular disease & & & \\
$\quad$ No & 1 & & \\
$\quad$ Yes & 1.21 & $1.00-1.46$ & 0.04 \\
Falls in the past twelve months & & & \\
$\quad$ No & 1 & & \\
$\quad$ Yes & 1.25 & $1.02-1.54$ & 0.02 \\
Hospitalization in the past twelve months & & & \\
$\quad$ No & 1 & & \\
$\quad$ Yes & 1.65 & $1.34-2.02$ & 0.00 \\
\hline
\end{tabular}

Note: PR - Prevalence Ratio; CI - Confidence Interval.

\section{DISCUSSION}

This study showed a $47.2 \%$ prevalence of frailty in the elderly assisted by the evaluated health reference center and allowed to know some associated factors.

We found no studies that evaluated prevalence of frailty in users assisted by the CRASI, which compromised more accurate comparisons. However, in studies using EFS, prevalence of fragility in the elderly who lived in the community was $39.1 \%$ in Ribeirão Preto, São Paulo ${ }^{(11)}$ and $41.3 \%$ in Montes Claros, Minas Gerais ${ }^{(6)}$, while in the elderly assisted by the Family Health Strategy in Embu, São Paulo, it was $30.1 \%^{(12)}$. Prevalence of frailty was $74.1 \%$ in the elderly of an institution of long permanence in Fortaleza, Ceará(13) , while it was $95.2 \%$ in the elderly hospitalized in the Medical Clinic of the Emergency Department of a University Hospital of Ribeirão Preto, São Paulo ${ }^{(14)}$. We observed that different conditions may influence the prevalence of frailty in the elderly.

Some factors may justify the disparities found in prevalence of frailty in the elderly, among them the consensual definition of this recently analyzed condition ${ }^{(3)}$, as well as the methodological standardization. Difficulties in standardizing the condition of frailty induces the diverse paths to the diagnosis. Various instruments with varied parameters, including differences regarding the composition of the sample, can compromise the comparison of results found in the studies ${ }^{(7,15-16)}$.

At first, a higher prevalence of frailty in the context of this study was expected, since the frail elderly has absolute indication for a specialized, multidisciplinary and multidimensional assessment, according to the criteria of the network for health care of the elderly, established by the Department of Health of the State of Minas Gerais ${ }^{(8)}$. The prevalence observed, slightly higher than the one registered among the community elderly, suggests that the criteria for referencing are not being followed or that maybe these criteria deserve to be reviewed. In this case, the use of EFS can be an alternative. Frailty develops as a consequence of decline in many physiological systems as age advances, resulting in vulnerability to changes triggered by health stressor events ${ }^{(7)}$. The EFS is considered to 
be a robust instrument for the capacity to evaluate the elderly in a multidimensional way, since there are nine aspects covered (cognition, state of health, functional independence, social support, medication use, nutrition, mood, urinary continence and functional performance $)^{(9-10)}$.

Although there are various instruments capable of indicating condition of frailty in the elderly, reliability and validity assessments were not performed on most of them. A systematic review found, between 1948 and May 2011, 150 studies that used 27 instruments on the evaluation of frailty in the elderly. Among them, only two, including the EFS, followed the guideline that discusses best practices in the development of complex measures. These instruments have demonstrated acceptable reliability as well as a concurrent, predictive and good validity ${ }^{(17)}$.

The results of this study confirm higher frequency of frailty as age increases, being more prevalent among the advanced age elderly; similar data have been found in other studies ${ }^{(6,13)}$. During the aging process, there is a gradual decrease of physiological reserve and consequent decline accumulated in several physiological systems, resulting in the condition of frailty ${ }^{7}$.

Regarding marital status, the condition of having no mate, being single, widowed or divorced was also associated with frailty. Pre-frailty condition was associated with the absence of a mate in a study carried out with elderly residents of the urban area of Uberaba, Minas Gerais ${ }^{(18)}$, a similar result to the one found in the pre-frail and frail Mexican elderly ${ }^{(19)}$. It is known that the condition of frailty is multidimensional and such findings underline the need to better understand determination of social factors connected with frailty in the elderly.

The results also showed association with frailty in the elderly who have a caregiver. Studies that used the EFS also observed this relation ${ }^{(6,20)}$. Probably, frail elderlies need a caregiver to assist them on their basic and instrumental activities demanded daily.

Depressive symptoms showed association with frailty, which also is consonant with other studies ${ }^{(21-22)}$. This association might be linked to characteristics present in both health conditions, such as inactivity, weight loss, exhaustion and low level of physical activity ${ }^{(22)}$.

Fragility was also associated with hospitalization in this and other studies ${ }^{(21,23)}$. Although the presence of NCD or its consequences does not always come along with frailty, its cumulative effects during the aging process lead to an increased risk of adverse events to health, resulting in frailty in the elderly and, consequently, adverse clinical outcome as hospitalization ${ }^{(7)}$.
Osteoarticular disease and fall were associated with frailty, which was also observed in some studies ${ }^{(3)}$. In Peru ${ }^{(24)}$, there was association of frailty with advanced age and fall last year. Study carried out in Ribeirão Preto $^{(25)}$ shows the largest fall occurrence in the frail elderly, using the EFS to evaluate frailty. Osteoarticular disease can compromise performance of routine activities of the elderly, executed without restrictions before, and risk of falling becomes imminent.

\section{Limitations of the study}

This study presents some limitations. It is derived from a cross-sectional study, in such a way that it is not possible to conclude the existence of causal association between frailty in the elderly and the associated factors mentioned here, which is feasible in longitudinal designs. In addition, we had a convenience sample, collected in a health reference center for the elderly, in which external validity is limited and results can be extrapolated only for a similar population. However, despite these limitations, this study has enough sample for adjustment of the regression models to major confusion factors of clinical interest, and used an standardized instrument, already adapted to the Brazilian culture. Besides, it presented similar results to those found in studies with a more robust methodology.

\section{Contributions to the nursing field}

The results show that conditions related to frailty are susceptible to intervention, which is fundamental to prevention and elderly health promotion, avoiding adverse clinical outcomes, especially considering aspects of frailty. Knowledge of factors associated with frailty allows development of health actions aimed at that population.

\section{CONCLUSION}

Prevalence of frailty was slightly higher than that registered on the elderly investigated in the community. We found a significant association of frailty in the advanced age elderly, living without a mate, however, with the presence of a caregiver. Regarding clinical conditions, we observed depressive symptoms, osteoarticular disease, as well as history of falls and hospitalization over the past twelve months are related to frailty in the elderly. The results evidence that conditions related to frailty are susceptible to intervention, which is clearly important to prevention and elderly health promotion, avoiding adverse clinical outcomes.

\section{REFERENCES}

1. Lima-Costa MF, Facchini LA, Matos DL, Macinko J. [Changes in ten years of social inequalities in health among elderly Brazilians (1998-2008)]. Rev Saúde Pública [Internet]. 2012 [cited 2016 Sep 04];46(Suppl1):100-7. Available from: http://www.scielo.br/pdf/ rsp/v46s1/ao4207.pdf Portuguese.

2. Veras, R. Can growing old in Brazil involve good health and quality of life? Rev Bras Geriatr Gerontol [Internet]. 2016 [cited 2016 Sep 04];19(3):381-2. Available from: http://www.scielo.br/pdf/rbgg/v19n3/1809-9823-rbgg-19-03-00381.pdf

3. Andrade AN, Fernandes MGM, Nóbrega MML, Garcia TR, Costa KNFM. Análise do conceito fragilidade em idosos. Texto Contexto Enferm [Internet]. 2012 [cited 2016 Sep 04];21(4):748-56. Available from: http://dx.doi.org/10.1590/S0104-07072012000400004

4. Campolina AG, Adami F, Santos JLF, Lebrão ML. A transição de saúde e as mudanças na expectativa de vida saudável da população 
idosa: possíveis impactos da prevenção de doenças crônicas. Cad Saúde Pública [Internet]. 2013 [cited 2016 Nov 30];29(6):121729. Available from: http://dx.doi.org/10.1590/S0102-311X2013000600018

5. Lana LD, Schneider RH. The frailty syndrome in elderly: a narrative review. Rev Bras Geriatr Gerontol [Internet]. 2014 [cited 2016 Sep 04];17(3):673-80. Available from: http://dx.doi.org/10.1590/1809-9823.2014.12162

6. Carneiro JA, Ramos GCF, Barbosa ATF, Mendonça JMG, Costa FM, Caldeira AP. Prevalência e fatores associados à fragilidade em idosos não institucionalizados. Rev Bras Enferm [Internet]. 2016 [cited 2016 Nov 30];69(3):435-42. Available from: http://dx.doi. org/10.1590/0034-7167.2016690304i

7. Clegg A, Young J, Iliffe S, RikkertMO, Rockwood K. Frailty in elderly people. Lancet [Internet]. 2013 [cited 2014 Mar 31];381(2):75262. Available from: http://www.thelancet.com/journals/lancet/article/PIIS0140-6736\%2812\%2962167-9/abstract

8. Minas Gerais. Secretaria do Estado de Saúde. Normas gerais do Programa Mais Vida - Rede de Atenção à Saúde do Idoso de Minas Gerais. Resolução SES n 2.603, de 07 de dezembro de 2010. Belo Horizonte, 2010.

9. Fabrício-Wehbe SCC, Schiaveto FV, Vendrusculo TRP, Haas VJ, Dantas RAS, Rodrigues RAP. Cross-cultural adaptation and validity of the "Edmonton Frail Scale - EFS" in a Brazilian elderly sample. Rev Latino-Am Enfermagem [Internet]. 2009 [cited 2014 Mar 31];17(6):1043-9. Available from: http://www.scielo.br/pdf/rlae/v17n6/18.pdf

10. Rolfson DB, Majumdar SR, Tsuyuki RT, Tahir A, Rockwood K. Validity and reliability of the Edmonton Frail Scale. Ag Ageing. 2006;35(1):526-9.

11. Fhon JRS, Diniz MA, Leonardo KC, Kusumota L, Haas VJ, Rodrigues RAP. Frailty syndrome related to disability in the elderly. Acta Paul Enferm [Internet]. 2012 [cited 2016 Sep 07];25(4):589-94. Available from: http://www.scielo.br/pdf/ape/v25n4/en_aop1812.pdf

12. Fernandes $\mathrm{HCL}$, Gaspar JC, Yamashita CH, Amendola F, Alvarenga MRM, Oliveira MAC. Avaliação da fragilidade de idosos atendidos em uma unidade da Estratégia Saúde da Família. Texto Contexto Enferm [Internet]. 2013 [cited 2016 Sep 07];22(2):423-31. Available from: http://dx.doi.org/10.1590/S0104-07072013000200019

13. Borges CL, Silva MJ, Clares JWB, Bessa MEP, Freitas MC. Avaliação da fragilidade de idosos institucionalizados. Acta Paul Enferm [Internet]. 2013 [cited 2016 Sep 07];26(4):318-22. Available from: http://dx.doi.org/10.1590/S0103-21002013000400004

14. Storti LB, Fabrício-WhebeSCC, Kusumota L, Rodrigues RAP, Marques S. Fragilidade de idosos internados na clínica médica da unidade de emergência de um hospital geral terciário. Texto Contexto Enferm [Internet]. 2013 [cited 2016 Sep 07];22(2):452-9. Available from: http://dx.doi.org/10.1590/S0104-07072013000200022

15. Collard RM, Boter H, Schoevers RA, Oude VRC. Prevalence of frailty in community-dwelling older persons: a systematic review. J Am Geriatr Soc [Internet]. 2012 [cited 2014 Mar 31];60(8):1487-92. Available from: http://onlinelibrary.wiley.com/ doi/10.1111/j.1532-5415.2012.04054.x/abstract

16. Tribess S, Oliveira RJ. Biological fragility syndrome in the elderly: systematic review. Rev Salud Pública [Internet]. 2011 [cited 2014 Mar 31];13(5):853-64. Available from: http://www.scielosp.org/pdf/rsap/v13n5/v13n5a14.pdf

17. Bouillon K, Kivimaki M, Hamer M, Sabia S, Fransson El, Singh-Manoux A, et al. Measures of frailty in population based studies: an overview. BMC Geriatr [Internet]. 2013 [cited 2014 Mar 31];13(1):60-4. Available from: http://bmcgeriatr.biomedcentral.com/ articles/10.1186/1471-2318-13-64

18. Pegorari MS, Tavares DMS. Factors associated with the frailty syndrome in elderly individuals living in the urban area. Rev Latino-Am Enfermagem [Internet]. 2014 [cited 2016 Sep 11];22(5):874-82. Available from: http://dx.doi.org/10.1590/0104-1169.0213.2493

19. Sánchez-García S, Sánchez-Arenas R, García-Peña C, Rosas-Carrasco O, Avila-Funes JA, Ruiz-Arregui L, et al. Frailty among community-dwelling elderly Mexican people: prevalence and association with sociodemographic characteristics, health state and the use of health services. Geriatr Gerontol Int. [Internet]. 2013 [cited 2016 Sep 11];14(2):395-402. Available from: https://www. ncbi.nlm.nih.gov/pubmed/23809887

20. Stackfleth R, Diniz MA, Fhon JRS, Vendruscolo TRP, Fabrício-Whebe SCC, Marques S, et al. Burden of work in caregivers of frail elders living at home. Acta Paul Enferm [Internet]. 2012 [cited 2014 Mar 31];25(5):768-74. Available from: http://www.scielo.br/ pdf/ape/v25n5/en_19.pdf

21. Vieira RA, Guerra RO, Giacomin KC, Vasconcelos KSS, Andrade ACS, Pereira LSM et al. Prevalência de fragilidade e fatores associados em idosos comunitários de Belo Horizonte, Minas Gerais, Brasil: dados do estudo FIBRA. Cad Saúde Pública [Internet]. 2013 [cited 2016 Sep 11];29(8):1631-43. Available from: http://dx.doi.org/10.1590/0102-311X00126312

22. Ramos GCF, Carneiro JA, Barbosa ATF, Mendonça JMG, Caldeira AP. Prevalência de sintomas depressivos e fatores associados em idosos no norte de Minas Gerais: um estudo de base populacional. J Bras Psiquiatr [Internet]. 2015 [cited 2016 Sep 11];64(2):12231. Available from: http://dx.doi.org/10.1590/0047-2085000000067

23. Remor CB, Bós AJG, Werlang MC. Características relacionadas ao perfil de fragilidade no idoso. SciMed [Internet]. 2011 [cited 2016 Sep 11];21(3):107-12. Available from: http://revistaseletronicas.pucrs.br/ojs/index.php/scientiamedica/article/download/8491/6716

24. Runzer-Colmenares FM, Samper-Ternent R, Al Snih S, Ottenbacher KJ, Parodi JF, Wong R. Prevalence and factors associated with frailty among Peruvian older adults. Arch Gerontol Geriatr [Internet]. 2014 [cited 2016 Sep 11];58(1):69-73. Available from: https://www.ncbi.nlm.nih.gov/pmc/articles/pmid/23978328/.

25. Fhon JRS, Rosset I, Freitas CP, Silva AO, Santos JLF, Rodrigues RAP. Prevalência de quedas de idosos em situação de fragilidade. Rev Saúde Pública [Internet]. 2013 [cited 2016 Nov 12];47(2):266-73. Available from: http://dx.doi.org/10.1590/S0034-8910.2013047003468 